\title{
RISK FACTORS OF TYPE II DIABETES MELLITUS AMONG WOMEN OF REPRODUCTIVE AGE IN SURAKARTA, CENTRAL JAVA
}

\author{
Anggi Putri Aria Gita1,2), Kusuma Estu Werdani²) \\ ${ }^{1)}$ Masters Program in Public Health, Universitas Sebelas Maret \\ ${ }^{2)}$ Department of Public Health, Faculty of Health Science, \\ Universitas Muhammadiyah Surakarta
}

\begin{abstract}
Background: Type 2 diabetes mellitus (DM) and its complications constitute a major worldwide public health problem. It results from a complex inheritance-environment interaction along with other risk factors such as obesity and sedentary lifestyle. The purpose of this study was to determine the risk factors of type II DM among women of reproductive age in Surakarta, Central Java.

Subject and Method: A case control study was carried out at Purwosari community health center. A sample of 150 women of reproductive age was selected by proportionate stratified random sampling. The dependent variable was type $2 \mathrm{DM}$. The independent variables were dietary pattern, body mass index (BMI), physical activity, and family history of DM. Data on type II DM were obtained from the medical record. The other data were collected by questionnaire and analyzed by a multiple logistic regression.

Results: The risk of type $2 \mathrm{DM}$ increased with low physical activity (OR $=3.27 ; 95 \%$ $\mathrm{CI}=1.53$ to 6.97; $\mathrm{p}=0.002)$, family history of $\mathrm{DM}(\mathrm{OR}=3.12 ; 95 \% \mathrm{CI}=1.43$ to $6.84 ; \mathrm{p}=$ 0.004), poor dietary pattern $(\mathrm{OR}=2.65 ; 95 \% \mathrm{CI}=1.20$ to $5.83 ; \mathrm{p}=0.016)$, and high $\mathrm{BMI}$ $(\mathrm{OR}=2.60 ; 95 \% \mathrm{CI}=1.27$ to $5.30 ; \mathrm{p}=0.008)$.
\end{abstract}

Conclusion: The risk of type $2 \mathrm{DM}$ increases with low physical activity, family history of DM, poor dietary pattern, and high BMI.

Keywords: type 2 DM, BMI, dietary pattern, physical activity

\section{Correspondence:}

Anggi Putri Aria Gita. Masters Program in Public Health, Universitas Sebelas Maret, Jl. Ir. Sutami 36A, Surakarta 57162, Central Java, Indonesia. Email: anggipag@gmail.com. Mobile: 08975406464. 